\title{
Evidence of GnRH Receptors in Cultured Pituitary Cells of the Winter Flounder (Pseudopleuronectes americanus W.)
}

\author{
C. Weil, ${ }^{*}, 1$ L. W. Crim, C. E. Wilson, and C. Cauty* \\ Ocean Sciences Centre, Memorial University of Newfoundland, St. John's, Newfoundland, Canada AIC 5S7; \\ and 'Laboratoire de Physiologie des Poissons, INRA, Campus de Beaulieu, 35042 Rennes Cedex, France
}

Accepted April 15, 1991

\begin{abstract}
For continued studies of GnRH receptor regulation in the winter flounder, we have developed an in vitro system consisting of cultured pituitary cells dissociated by collagenase. Using immunocytochemical staining methods for gonadotropin, growth hormone, and prolactin, these cell types were represented at the levels of 25,20 , and $19.5 \%$ of total pituitary cell population, respectively. Receptors for GnRH were characterized in intact monolayered attached pituitary cells, maintained in RPMI culture medium. The cell GnRH receptor characteristics were compared with those previously described using pituitary homogenates. The cells were capable of binding GnRH in a similar manner on Day 2 or Day 3 of culture, indicating the integrity of GnRH receptors. The specificity of binding was demonstrated since only high doses of cold GnRHa competed with ${ }^{125} \mathrm{I}-\mathrm{GnRHa}$ uptake, different peptides being without effect. The specific binding is saturable and the data suggest the presence of a single class of high-affinity (apparent $K_{a}=1.50 \times 10^{9} \mathrm{M}^{-1}$ ), high-capacity sites (binding capacity $=25.03 \mathrm{fmol} / 2.5 \times 10^{5}$ cells or $242.23 \times 10^{3}$ sites/gonadotroph) which is in accordance with the characteristics of GnRH receptors present in homogenates of pooled male and female pituitary glands. All these observations suggest that such an in vitro pituitary cell system would be appropriate for studying GnRH receptor characteristics under different physiological conditions. 1992 Academic Press, Inc.
\end{abstract}

Characterization of GnRH receptors in disrupted cells of the fish pituitary has been previously conducted using homogenates (Crim et al., 1988a; Anderson et al., 1989) or membrane preparations (Habibi et al., 1987; De Leeuw et al., 1988a). These studies all demonstrate the presence of highaffinity, specific-binding sites for GnRH analogs in the fish pituitary gland.

Further studies concerning the physiological regulation of fish pituitary GnRH receptors could be improved by utilizing intact cultured pituitary cells. Such a method was used for example by Naor et al. (1980) and Andries and Denef (1986) to characterize GnRH receptors in the mammalian pituitary gland. Such a technique was re-

\footnotetext{
1 To whom correspondence and reprint requests should be addressed.
}

cently utilized for fish, using unattached cultured pituitary cells (De Leeuw et al., 1989). We decided to examine GnRH receptor characteristics in winter flounder cultured pituitary cells comparing the GnRH receptor results previously obtained with pituitary homogenates in this species (Crim et al., 1988a).

\section{MATERIALS AND METHODS}

Experimental animals. Sexually mature, prespawning male and female winter flounder were collected from inshore waters of Conception Bay, Newfoundland, by scuba divers during April-May 1989. The fish were temporarily held in the Ocean Sciences Centre Laboratory in ambient sea water.

Preparation of pituitary cultures. The procedures for preparing dispersed and cultured cells from flounder pituitary glands were adapted from the methods described for trout (Weil et al., 1986).

For the flounder pituitary, the main technical changes included modifications in $\mathrm{pH}$ and osmotic 
pressure of the culture medium (RPMI buffered with $20 \mathrm{mM}$ Hepes and $9 \mathrm{mM} \mathrm{NaHCO}$ ) which were adapted to blood plasma values of this species (7.2 and $315 \mathrm{mosm} / \mathrm{kg}$, respectively). The temperature of incubation was changed to $5^{\circ}$ which is consistent with normal spring living conditions for the flounder.

Pituitary glands, collected after decapitation of 6 to 12 fish according to the experiments, were pooled and chopped into small pieces. Cell dispersion was performed using collagenase $(0.1 \%$ in culture medium) for $16 \mathrm{hr}$ at $5^{\circ}$ and aided by mechanical dispersion at the end of the enzyme incubation period. Cells were harvested by centrifugation $(200 \mathrm{~g}, 10 \mathrm{~min})$ and washed twice with culture medium supplemented with $2 \%$ of a serum substitute (ultroser SF) and $1 \%$ antibioticantimyicotic mixture $(100 \mathrm{U} / \mathrm{ml}$ penicillin, $100 \mu \mathrm{g} / \mathrm{ml}$ streptomycin, $0.25 \mu \mathrm{g} / \mathrm{ml}$ fungizone). The cells were diluted to $2.5 \times 10^{5} / \mathrm{ml}$ and $1 \mathrm{ml}$ of suspension was plated into each well of 24-multiwell plastic plates coated with poly-L-lysine $\left(5 \mu \mathrm{g} / \mathrm{cm}^{2}\right)$. Cell counting and cell viability were determined using a Thoma hemocytometer in the presence of trypan blue.

Radioreceptor assay. (D-Ala ${ }^{6}$, Pro ${ }^{9} \mathrm{Net}$ ) GnRH (GnRHa) was selected among different GnRH based on optimum binding of this labeled peptide by flounder pituitary homogenate (unpublished results).

Iodination and HPLC purification of this analog were performed as previously described for buserelin (D-Ser(tBu6), Pro ${ }^{9}$ Net LHRH) (Crim et al., 1988a). The specific activity of the labeled GnRHa was determined by self-displacement as previously described for buserelin (Crim et al., 1988a) and was $1 \mathrm{mCi} / \mu \mathrm{g}$.

The radioreceptor technique was conducted with attached cells in the culture wells as follows. On the second or third day of culture, according to the experiments, culture medium was discarded, cells were washed with $400 \mu \mathrm{l}$ RPMI-0.1\% BSA. Incubation was performed in triplicate with ${ }^{125} \mathrm{I}-\mathrm{GnRHa}(100,000 \mathrm{cpm}$ $\approx 60 \mathrm{fmol}$ ) and $1 \mu \mathrm{g}$ cold $\mathrm{GnRHa}$ for nonspecific binding (total incubation volume, $300 \mu 1$ ). At the end of the incubation period, medium was discarded, and the cells were washed with $400 \mu$ l of RPMI $-0.1 \%$ BSA, scraped free using $300 \mu$ l of the same buffer, and transferred to glass tubes for counting the radioactivity. The specifically bound radioactivity was calculated by subtracting the nonspecifically bound (mean of triplicate determinations) from the total bound radioactivity (mean of triplicate determinations).

Affinity constants $\left(K_{a}\right)$ and number of binding sites $(R)$ were estimated from the Scatchard (1949) transformation of saturation and competition curves for specific binding of ${ }^{125} \mathrm{I}-\mathrm{GnRHa}$. The linear regression was calculated by using a computerized program (Fig. P). This program was also used for analysis of displacement curves and determination of ED50.

Immunocytochemical staining for cultured cells and pituitary sections. The immunocytochemical staining of gonadotrophs, somatotrophs, and prolactin cells (in culture or on sections) was performed using the peroxidase procedure. The staining reaction consisted of a solution of 4-chloro-1-naphtol in $0.05 \mathrm{M}$ ammonium acetate-citric acid buffer, pH 5. The rabbit antisera used for gonadotropic, somatotropic, and prolactin cells were raised against the $\beta$ subunit of carp gonadotropin (GtH) (gift of B. Breton), chinook salmon growth hormone (GH) (gift of P. Y. Le Bail), chinook salmon prolactin (PRL) (gift of P. Prunet), respectively. They were tried at the following dilutions: $1 / 100,1 / 250,1 / 500,1 / 1000$, and $1 / 2500$. In final works the antibodies were diluted $1 / 1000$ since such a dilution allows specific staining and good reproducibility between replicate experiments. Control reactions were carried out using normal rabbit serum at the same dilution.

For cultured flounder pituitary cells the work was performed using the technique described by Dacheux (1981) for cultured pig pituitary cells and adapted for cultured rainbow trout pituitary cells (Weil et al., in preparation). On Day 3 of culture, the immunocytochemical staining was applied directly on attached cells and fixed in the wells in picric acid formaldehyde solution according to Zamboni and de Martino (1967) for $5 \mathrm{hr}$ at room temperature. The positive cells could be easily identified and counted. The percentage of cells of a certain type is the result of two independent dispersions performed separately each time on male and female pituitaries. At each dispersion, for each antibody 200-600 cells have been counted on duplicates.

For pituitary sections, immunocytochemical staining was performed on 5- $\mu \mathrm{m}$ sections fixed in Bouin's Hollande sublimate. Four different pituitaries were examined and immunostaining was performed on 8 to 12 sections for each antibody and controls.

\section{RESULTS}

\section{Pituitary Culture}

Following collagenase dispersion, the number of pituitary cells recovered varied according to the size of the donor fish: $25 \times$ $10^{4}, 40 \times 10^{4}$, and $10 \times 10^{5}$ cells for fish with body weights of $0.2,0.4$, and $1.0 \mathrm{~kg}$, respectively.

Primarily, single cells were collected with a few clusters of cells. The average yield of living cells (for nine trials) was 92.9\% based upon the trypan blue exclusion test.

After plating, cells attached to the plastic only after its pretreatment with poly-Llysine. Under such conditions cells were at- 
tached by Day 1 and spread during the second and third days.

On Day 3, GtH cells were evident by immunochemistry (Fig. 1) and represented $25 \%$ of the total cultured cells collected from prespawning male and female fish. On the other hand, growth hormone and prolactin cells represent 20 and 19\%, respectively.

To assess the specificity of the immunolabeling of dispersed GtH, PRL, and GH cells, immunostaining of these pituitary hormones was performed on pituitary sections (Fig. 2). GtH antibody reacted with cells located in the periphery of the proximal pars distalis while $\mathrm{GH}$ antibody reacted with cells situated in the internal part. PRL antibody revealed cells localized in the rostral pars distalis.

\section{GnRH Receptor Binding Activity}

Female winter flounder were collected in April for determining GnRHa receptor binding activity in cultured pituitary cells. The first experiment (Table 1) was conducted to determine the effect of varying incubation times on the level of specific GnRHa binding. A significant level of binding $(6.4 \%)$ was obtained after $1.5 \mathrm{hr}$ of incubation; specific binding continued increasing, rising to $9.8 \%$ by $4 \mathrm{hr}$, reaching equilibrium since binding remained greater than $9 \%$ for the 10- and 24-hr sampling periods. A 4-hr incubation period was selected for the remaining experiments.
In another experiment with female pituitaries the influence of number of days for cells in culture was examined; the data (Table 2) again indicate that specific binding increases with duration of incubation and that similar levels of GnRHa binding are achieved on both Day 2 and Day 3 of cell culture. Therefore, GnRHa receptor assays could be performed on either Day 2 or Day 3 of culture.

The capacities of 2-day-cultured female and male pituitary cells to bind labeled GnRHa as well as the specificity of the GnRHa binding were compared in a subsequent experiment (Figs. 3 and 4). Comparable levels of total specific GnRHa binding, 10.1 and $9.8 \%$ for female and male cells, respectively, were achieved. In female and male cultures, specific binding could be inhibited by increasing doses of GnRHa and in the presence of $10^{-8} M$ GnRHa, full displacement of labeled GnRHa was obtained, and the ED50 was 2 $\times 10^{-10} M$ in both cases (Figs. 3A and 4A). On the other hand, in female cultures (Fig. 3A) we observed a lack of significant labeled GnRHa displacement by micromolar amounts of peptide hormones unrelated to GnRHa. The percentages of binding in the presence of oxytocin, thyrotropic-stimulating hormone, or Met-enkephalin were 9.9, 8.3 , and $9.8 \%$, respectively, while total specific binding was $10.1 \%$. These results suggest that cultured flounder pituitary cells bind GnRHa in a specific manner. Taking
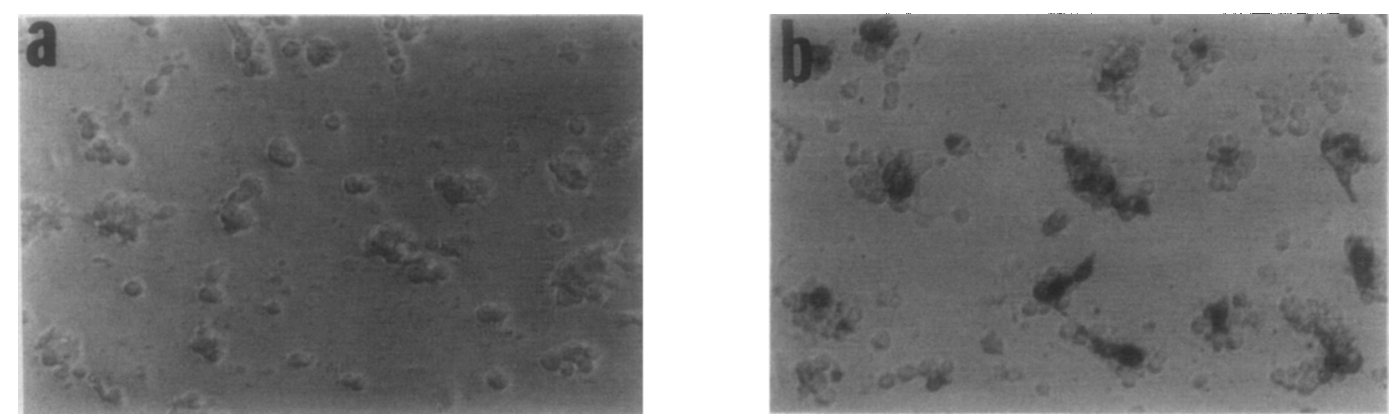

Fig. 1. Immunostaining of 3-day-cultured gonadotropic cells using (a) an antibody raised against carp $\beta-G t H$, positive cells are stained in black, and (b) control rabbit serum. 

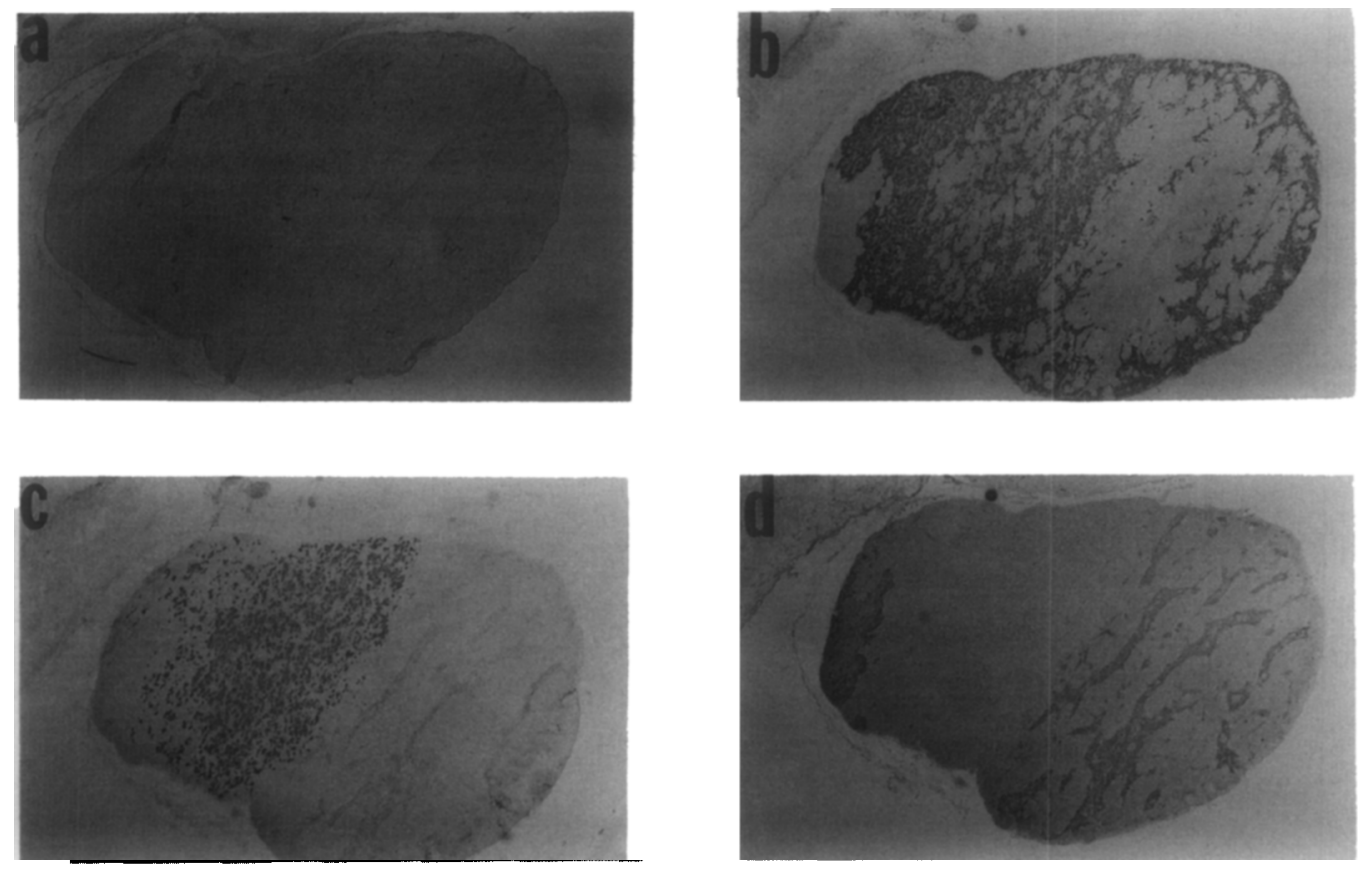

FIG. 2. Immunostaining of serial sagittal pituitary sections from prespawning male using (a) control rabbit serum or antibodies raised against $\alpha$ (b) carp $\beta-G t H$, (c) salmon $G H$, and (d) salmon prolactin.

into account only the doses of cold GnRH displacing significantly the bound hormone, the Scatchard transformation of the female (Fig. 3B) and male (Fig. 4B) displacement curves provided evidence for a population of binding sites with a high affinity for GnRH (apparent $K_{a}=0.3910^{9} M^{-1}$ and $2.2910^{9} M^{-1}$ for females and males, respectively) and binding capacities $(R)$ of $89.24 \mathrm{pM}$ (or $26.77 \mathrm{fmol} / 2.5 \times 10^{5}$ cells) and $17.98 \mathrm{pM}$ (or $5.39 \mathrm{fmol} / 2.5 \times 10^{5}$ cells) for the females and the males, respectively.

\section{TABLE 1}

Time Course of GnRH Binding for Female Pituitary Cells on Day 2 of Culture

\begin{tabular}{ccc}
\hline $\begin{array}{c}\text { Duration of } \\
\text { incubation } \\
(\mathrm{hr})\end{array}$ & $\begin{array}{c}\text { Specific } \\
\text { binding } \\
(\%)\end{array}$ & $\begin{array}{c}\text { Nonspecific } \\
\text { binding } \\
(\%)\end{array}$ \\
\hline 1.5 & $6.34 \pm 0.19$ & $1.37 \pm 0.07$ \\
4 & $9.75 \pm 0.15$ & $1.24 \pm 0.06$ \\
10 & $9.56 \pm 0.74$ & $1.17 \pm 0.17$ \\
24 & $9.34 \pm 0.18$ & $0.81 \pm 0.04$ \\
\hline
\end{tabular}

Note. Values are the mean $\pm \mathrm{SE}$ of three wells containing $2.5 \times 10^{5}$ cells obtained from six fish.
Taking into account that $25 \%$ of the cells are gonadotrophs and assuming that the distribution of the receptors is homogeneous, the GnRH binding capacity was $259.5 \times 10^{3}$ and $52.3 \times 10^{3}$ sites/gonadotroph for the females and the males, respectively.

One month later, the GnRHa receptor characteristics were examined in a pool of cultured male and female flounder pituitary cells by saturation analysis. In the presence of increasing amounts of ${ }^{125} \mathrm{I}$-GnRHa, nonspecific binding behaved linearly and was not saturable while specific binding was saturable (Fig. 5A). The Scatchard-derived curve revealed (Fig. 5B) a single class of binding sites with a binding capacity $(R)$ of $83.29 \mathrm{p} M\left(25.03 \mathrm{fmol} / 2.5 \times 10^{5}\right.$ cells corresponding to a quarter of digested pituitary or $242.23 \times 10^{3}$ sites/gonadotroph) and a high-binding affinity (apparent $K_{a}=1.50 \times$ $\left.10^{9} M^{-1}\right)$. These values are the mean obtained in two independent experiments, the characteristics of the GnRHa receptors be- 
TABLE 2

Influence of the Duration of Maintenance in Culture on the GnRH Binding by Female Pituitary Cells

\begin{tabular}{cccc}
\hline $\begin{array}{c}\text { Day of } \\
\text { culture }\end{array}$ & $\begin{array}{c}\text { Duration of } \\
\text { incubation }(\mathrm{hr})\end{array}$ & $\begin{array}{c}\text { Specific binding } \\
(\%)\end{array}$ & $\begin{array}{c}\text { Nonspecific binding } \\
(\%)\end{array}$ \\
\hline 2 & 1.5 & $2.99 \pm 0.11$ & $2.05 \pm 0.22$ \\
& 4 & $5.16 \pm 0.39$ & $0.77 \pm 0.05$ \\
3 & 1.5 & $3.59 \pm 0.04$ & $1.36 \pm 0.11$ \\
& 4 & $5.32 \pm 0.26$ & $1.35 \pm 0.08$ \\
\hline
\end{tabular}

Note. Values are the mean $\pm \mathrm{SE}$ of three wells containing $2.5 \times 10^{5}$ cells obtained from six fish.

ing 74.92 and $91.67 \mathrm{p} M$ for $R$ and $1.8610^{9} \times$ $M^{-1}$ and $1.14 \times 10^{9} M^{-1}$ for apparent $K_{a}$, respectively.

\section{DISCUSSION}

The annual reproductive cycle of the winter flounder can be divided into four distinct phases: (1) an inactive period when the gonads are regressed during the early summer; (2) the resumption of reproductive activity, a period of gonadal recrudescence, in late summer and the fall; (3) a long winter prespawning period of relatively developed gonads; and (4) a short spawning period in May and June (Harmin and Crim, unpublished). The work of Crim et al. (1987) showed that GnRH receptor levels fluctu- ate from a peak at spawning to much lower levels in fish during the period of gonadal regression. Therefore, we have chosen to work with pituitaries collected from flounder obtained during prespawning season (April-May).

Pituitary cells were dispersed with collagenase treatment and the yield. of living cells was high (93\%) and in accordance with the best results obtained with different species and different procedures (carp, Ribeiro et al., 1983; trout, Farheus-Van-Ree et al., 1982; Weil et al., 1986; catfish, De Leeuw et al., 1984; goldfish, Chang et al., 1990). The number of cells recovered in relation with fish body weight is similar to that we previously obtained with trout (Weil et al., 1986). We observed a difference between

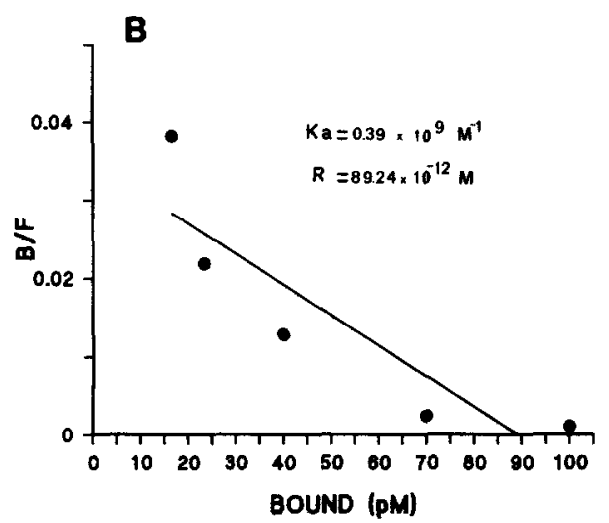

Fig. 3. (A) The ${ }^{125} \mathrm{I}-\mathrm{G}$ RHHa displacement curve for female cultured pituitary cells in the presence of increasing quantities of cold GnRHa $\left(10^{-11}\right.$ to $\left.10^{-6} \mathrm{M}\right)$ and unrelated peptides such as oxytocin (1.5 $\times 10^{-5} M$ ), Met-Enkephalin (M-ENK, $2 \times 10^{-5} M$ ), and thyrotropin-releasing hormone (TRH, $3 \times$ $10^{-5} M$ ). Values are the mean $\pm \mathrm{SE}$ of three wells containing $2.5 \times 10^{5}$ cells obtained from nine fish. (B) Scatchard plot of the displacement curve data (taking into account the doses of cold GnRHa giving significant displacement. $K_{a}$, equilibrium association constant; $R$, receptor density). 

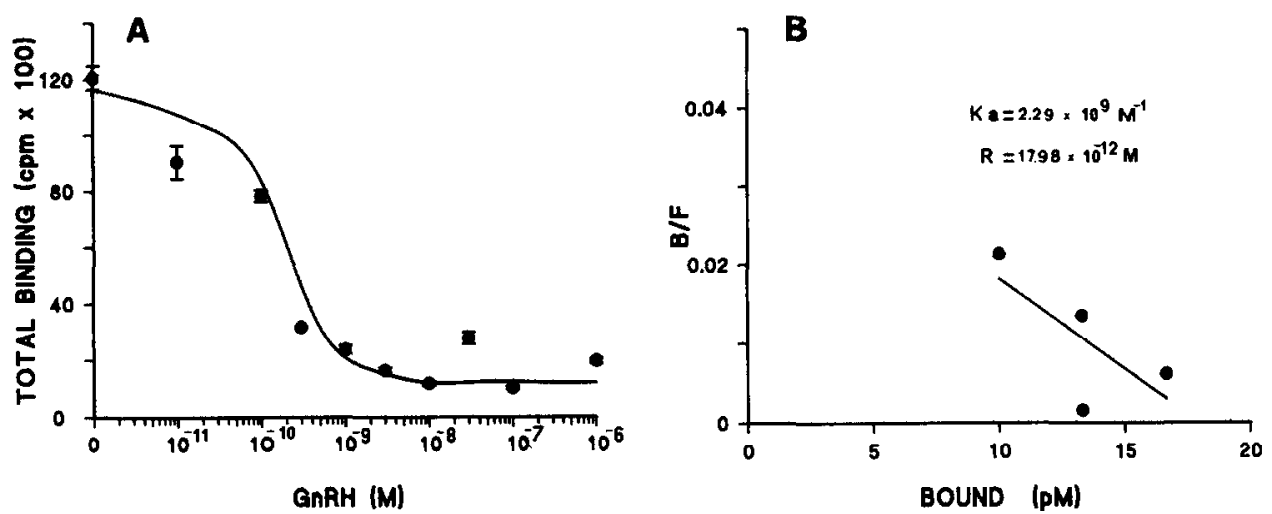

FIG. 4. (A) The ${ }^{125}$ I-GnRHa displacement curve for male cultured pituitary cells in the presence of increasing quantities of cold GnRHa $\left(10^{-11}\right.$ to $\left.10^{-6} \mathrm{M}\right)$. Values are the mean $\pm \mathrm{SE}$ of three wells containing $2.5 \times 10^{5}$ cells obtained from seven fish. (B) Scatchard plot of the displacement curve data (taking into account the doses of cold GnRHa giving significant displacement. $K_{a}$, equilibrium association constant; $R$, receptor density).

the two fish species concerning attachment of pituitary cells to plastic plates. For winter flounder a pretreatment of the plates by poly-L-lysine is necessary, indicating an insufficiency either in the amount of attachment factors present in the serum substitute (ultroser) used at $2 \%$ or in the production of fibronectin by the fibroblasts (Furcht, 1983) which are much less numerous in cultured cells from winter flounder than from trout.

In prespawning winter flounder, GtH cclls are present among the cultured pituitary cells and represent about $25 \%$ while growth hormone and prolactin cells represent 20 and $19 \%$, respectively. The specificity of the identification of dispersed $\mathrm{GtH}$, GH, and PRL cells by immunochemistry was assessed by comparison with their location in pituitary sections. GtH cells are located along the periphery of the pars distalis while GH cells are located in the internal part; this pituitary localization is in ac-
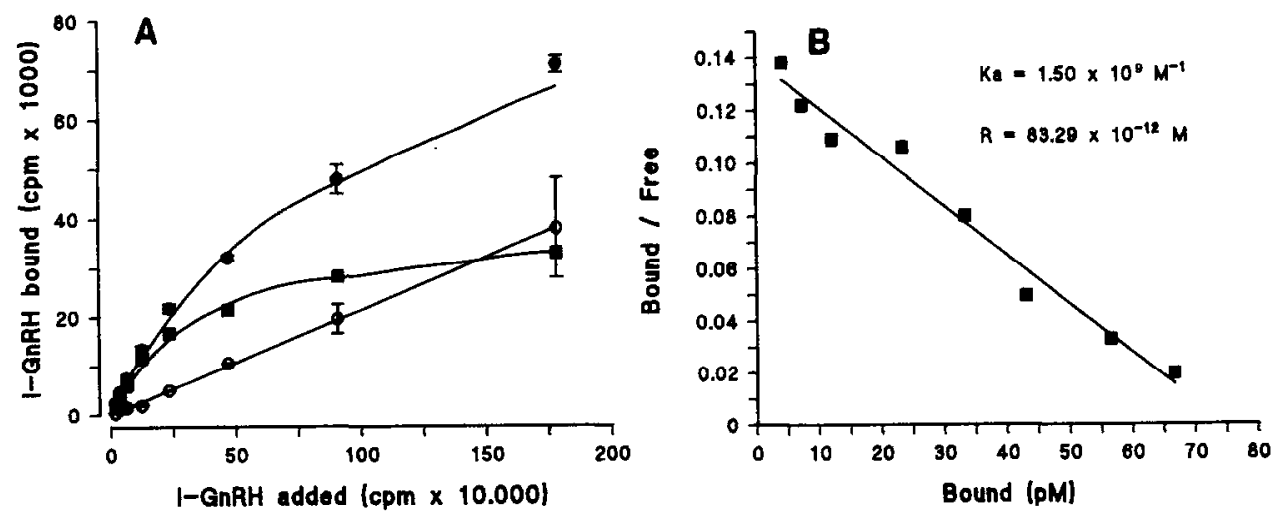

FIG. 5. One representative experiment of (A) saturation data for pooled male and female cultured pituitary cells in the presence of increasing quantities of ${ }^{125}$ I-GnRHa. (O) Total tracer binding $(\bar{x} \pm$ SE); (O) nonspecific binding in the presence of $10^{-6} \mathrm{M}$ of $\mathrm{GnRHa}(\bar{x} \pm \mathrm{SE})$; ( $(\mathbb{)})$ specific binding of the tracer, calculated as the difference between the total and the nonspecific binding of the tracer. Results were obtained on triplicate wells containing $2.5 \times 10^{5}$ cells obtained from 12 fish. (B) Scatchard transformation of the saturation data. Values for $K_{a}$, equilibrium association constant, and $R$, receptors density, are the means obtained from two independent experiments. Individual values are given in the text. 
cordance with the description made in sole by Nunez-Rodriguez (1985), also using an anti-carp $\beta$-GtH and comparing with classical histology. Prolactin cells revealed by an anti-salmon PRL are localized in the rostral pars distalis as described for winter flounder ( $\mathrm{Ng}$ et al., 1980) and sole (NunezRodriguez, 1985) with the same antibody as ours.

These intact winter flounder monolayered pituitary cells bind GnRHa after 2 and 3 days in culture; specific binding is high (nonspecific binding being low) and it represents about $80 \%$ of total binding. Similar results showing specific binding of $\mathrm{GnRH}$ were found in the rat by Andries and Denef (1986), using intact rat pituitary cells attached to coverslips. The present work does not allow us to know if GnRHa internalization could occur during the 4-hr incubation period at $5^{\circ}$ and if the apparent specific binding is only due to GnRHa fixation to the external surface of plasma membrane. In fish, no data are available on the existence and the kinetic of the GnRHreceptor complex internalization, while, in mammalian pituitary culture, internalization of LHRH agonists has been reported to occur after $30 \mathrm{~min}$ of incubation at $25^{\circ}$ (Naor et al., 1981).

In winter flounder there is strong evidence that the specific binding of ${ }^{125} \mathrm{I}$ GnRHa to cultured pituitary cells represents binding to a biologically relevant GnRH receptor since only high doses of GnRHa, and not peptides of different structure, caused displacement of labeled GnRHa.

In our present work the specific binding of GnRHa obtained with $2.5 \times 10^{5}$ cells (corresponding to a quarter of pituitary of one kilo fish) is similar to that obtained with homogenate corresponding to the same amount of pituitary from fish at the same stage of sexual development (Crim et al., 1987). This observation is consistent with the presence of intact receptors in cultured cells. The integrity of receptors and their number remain stable with the duration of incubation since the percentage of specific binding is similar on Day 2 or Day 3 of culture. On the contrary, in the rat Naor et al. (1980) observed a decrease in GnRH binding of collagenase-dispersed cells with time of the incubation period, indicating a loss in the number of GnRH cell receptors.

The integrity of the GnRH receptors present in winter flounder cultured male and female pituitary cells was also assessed by the similarity of their characteristics revealed by saturation and Scatchard analysis when compared to that obtained with pituitary homogenates (Crim et al., 1988a). In 3-day pooled male and female cultured cells the specific binding is saturable and characteristic of a single class of high-affinity sites (apparent $K_{a}=1.501 \times 10^{9} \mathrm{M}^{-1}$ ) with a high-binding capacity of $25.03 \mathrm{fmol} / 2.5 \times$ $10^{5}$ cells. Taking into account that $2.5 \times 10^{5}$ cells correspond to a quarter of pituitary and hypothesizing that the yield of recovered cells after dissociation represents $45 \%$ of initial cells (as we have found in trout; Le Goff, 1990) this binding capacity is equivalent to $220.77 \mathrm{fmol} /$ pituitary, a value in accordance with that previously found with pituitary homogenates from sexually mature males and females $(165 \mathrm{fmol} /$ pituitary; Crim et al., 1988a). Since the cultured pituitary cells contain about $25 \%$ gonadotrophs, the binding capacity is equivalent to about $242.23 \times 10^{3}$ receptor sites per gonadotroph, a value higher but in accordance with that observed in rat (Loumaye and Catt, 1983; Andries and Denef, 1986). The apparent $K_{a}$ obtained in the present work using pooled male and female pituitary cells (saturation analysis), although being about five times higher than previously observed with homogenates (Crim $e t$ al., 1988a), is in the same range of magnitude. The difference might be due to the fact that the two analyses were performed in different experiments using different labeled $\mathrm{GnRH}$ analogs, (D-Ser(tBu $\left.{ }^{6}\right)$, Pro' ${ }^{9}$ et LHRH) in the previous study, (D- 
$\mathrm{Ala}^{6}$, Pro ${ }^{9}$ Net LHRH) in the present work. Indeed, by using pituitary homogenates we have shown (Crim et al., 1988b) that the latter analog has a lower ED50 for receptor binding, indicating a higher affinity for flounder GnRH receptors. On the contrary, in catfish the relative binding affinity of buserelin to pituitary membrane receptors is higher compared to (D-Ala ${ }^{6}$, Pro ${ }^{9}$ Net LHRH) (De Leeuw et al., 1988b).

From the competition analysis performed about 1 month before spawning, it appears that the characteristics of the receptors are slightly different in females and males. Further works are in progress to compare in fish of both sexes the characteristics of the GnRH receptors throughout the sexual cycle.

In conclusion, our present investigation indicates that the use of intact cultured winter flounder pituitary cells is valid and convenient for studying GnRH receptor characteristics. Binding is highly specific since about $80 \%$ of total binding represented binding to saturable pituitary high-affinity sites as previously found with pituitary homogenates. Intact pituitary cells will be a useful model for studying the regulation of GnRH receptors by different factors such as steroids since we previously demonstrated that castration increases the GnRH binding capacity of male pituitary homogenates (Crim et al., 1987).

\section{ACKNOWLEDGMENTS}

We thank Ms. D. Steves for technical assistance and Ms. M. Boland for typing the manuscript. The visits of C. Weil to St. John's were supported by a NATO grant and INRA. Ocean Sciences Centre Contribution Number 89 .

\section{REFERENCES}

Anderson, E., Borg, B., and De Leeuw, R. (1989). Characterization of gonadotropin-releasing hormone binding sites in the pituitary of the threespined stickleback, Gasteroteus aculeatus. Gen. Comp. Endocrinol. 76, 41-45.

Andries, M., and Denef, C. (1986). Characterization of luteinizing hormone-releasing hormone receptor binding in rat pituitary cell monolayer cultures: Influence of intercellular communication. Mol. Cell. Endocrinol. 44, 147-158.

Chang, J. P., Cook, H., Freedman, G. L., Wiggs, A. J., Somoza, G. M., De Leeuw, R., and Peter, R. E. (1990). Use of pituitary cell dispersion method and primary culture system for the studies of gonadotropin-releasing hormone action in the goldfish, Carassius auratus. Gen. Comp. Endocrinol. 77, 256-273.

Crim, L. W., Wilson, C. E., St. Arnaud, R., Evans, D. M., and Harmin, S. A. (1987). Characteristics of fish pituitary LHRH receptors. In "Proceedings, Third International Symposium of Fish Reproduction, St. John's, Newfoundland."

Crim, L. W., St. Arnaud, R., Lavoie, M., and Labrie, F. (1988a). A study of LH-RH receptors in the pituitary gland of the winter flounder (Pseudopleuronectes americanus Walbaum). Gen. Comp. Endocrinol. 69, 372-377.

Crim, L. W., Nestor, J. J., and Wilson, C. E. (1988b). Studies of the biological activity of LHRH analogs in the rainbow trout, landlocked salmon, and the winter flounder. Gen. Comp. Endocrinol. 71, 372-378.

Dacheux, F. (1981). Ultrastructural localization of gonadotropin-releasing hormone in the porcine gonadotropic cells. Cell Tissue Res. 216, 143-150.

De Leeuw, R., Goos, H. J. Th., Peute, J., Van Pelt, A. M. M., Burzawa-Gerard, E., and Van Oordt, P. G. W. J. (1984). Isolation of gonadotrophs from the pituitary of the African catfish, (Clarias lazera): Morphological and physiological characterization of the purified cells. Cell Tissue Res. 236, 669-675.

De Leeuw, R., Conn, P. M., Van't Veer, C., Goos, H. J. Th., and Van Oordt, P. G. W. J. (1988a). Characterization of the receptor for gonadotropinreleasing hormone in the pituitary of the African calfish, Clarias gariepinus. Fish. Physiol. Biochem. 5, 99-107.

De Leeuw, R., Van't Veer, C., Smit-Van Dijk, W., Goos, H. J. Th., and Van Oordt, P. G. W. J. (1988b). Binding affinity and biological activity of gonadotropin-releasing hormone analogs in the African catfish, Clarias gariepinus. Aquaculture 71, 119-131.

De Leeuw, R., Larteveer, F. D., Van Deer Meer, M., Zandbergen, T. A., Goos, H. J. Th., and Van Oordt, P. G. W. J. (1989). Use of catfish pituitary cell cultures in studies of gonadotropin-releasing hormone (GNRH) receptor binding and action. In "Proceedings, XIth International Symposium on Comparative Endocrinology, Malaga, Spain," p. 96. [Abstract]

Fahraeus-Van-Ree, G. E., Guldenar, S. E. F., and Gielen, J. T. (1982). Fine structure and function 
of isolated gonadotropin cells as revealed from pituitaries of immature rainbow trout (Salmo gairdneri), by means of a new enzymatic dispersion technique. Cell Tissue Res. 226, 641-653.

Furcht, R. (1983). Function of the adhesive glycoprotein fibronectin. Mol. Cell. Biol. 1, 53-117.

Habibi, H. R., Peter, R. E., Sokolowska, M., Rivier, J., and Vale, W. W. (1987). Characterization of gonadotropin-releasing hormone (GnRH) binding to pituitary receptors in goldfish (Carassius auratus). Biol. Reprod. 36, 844-853.

Le Goff, P. (1990). Contribution à l'étude du contrôle de la sécrétion de prolactine et de l'expression de ce gène chez la truite arc-en-ciel (Oncorhyncus mykiss). Thèse de doctorat d'état, Université de Rennes I.

Loumaye, E., and Catt, K. J. (1983). Agonist-induced regulation of pituitary receptors for gonadotropinreleasing hormone; dissociation of receptor recruitment from hormone release in cultured gonadotrophs. J. Biol. Chem. 285, 12,002-12,009.

Naor, Z., Clayton, R. N., and Catt, K. J. (1980). Characterization of gonadotropin-releasing hormone receptors in cultured pituitary cells. Endocrinology 107, 1144-1152.

Naor, Z., Atlas, D., Clayton, R. N., Forman, D. S., Amsterdam, A., and Catt, K. J. (1981). Fluorescent derivative of gonadotropin-releasing hormone: Visualization of hormone receptor interac- tion in pituitary cells. J. Biol. Chem. 256, 30493052.

Ng, T. B., Idler, D. R., and Burton, M. (1980). A comparison of prolactins from a marine, and estuarine and a freshwater teleost. Gen. Comp. Endocrinol. 42, 141-146.

Nunez-Rodriguez, J. (1985). Contribution à l'étude de la biologie de la reproduction de la sole (Solea vulgaris Quensel, 1806): approche ultrastructurale et physiologique. Thèse de Doctorat, Université de Bordeaux I.

Ribeiro, L., Ahne, W., and Lichtenberg, V. (1983). Primary culture of normal pituitary cells of carp (Cyprinus carpio) for the study of gonadotropin release. In Vitro 19, 41-45.

Scatchard, G. (1949). The attraction of proteins for small molecules and ions. Ann. N.Y. Acad. Sci. $51,660-672$.

Weil, C., Hansen, P., Hyam, D., Le Gac, F., Breton, B., and Crim, L. W. (1986). Use of pituitary cells in primary culture to study the regulation of gonadotropin hormone (GtH) secretion in rainbow trout: Setting up and validating the system as assessed by its responsiveness to mammalian and salmon gonadotropin releasing hormone. Gen. Comp. Endocrinol. 62, 202-209.

Zamboni, L., and de Martino, C., (1967). Buffered picric acid and formaldehyde: $A$ new rapid fixation for electron microscopy. J. Cell Biol. 35, 148A. 